The proclamation in an issue of The Library Muse from the University of Missouri Library proclaiming April as Book Desecration Month, along with the presentation of the official Don't Care Bear symbol, may be, in part, an effort to focus attention on untoward user behavior but it too carries with it just a hint of discomfort about preservation efforts. The description and illustration in that same issue of Saint Asafoetida-the Patron Saint of Book Preservation, also known as the Blessed Fumigator-who "felt the call of her venerated profession and abandoned library school to wander through the midwestern libraries spreading the Doctrine of Preservation" clearly expresses the concern that many librarians seem to have with the too ardent dedication of their colleagues who have seen the preservation light. In their zeal those colleagues can become easy targets for fun. For that we should be thankful.

Our concerns may be especially evident when those nasty preservation librarians attempt to impose their doctrines in ways that affect the personal habits of users and/or staff in relationship to the consumption of food and drink in the proximity of library materials. As the New York University Libraries videotape and the Fairfield University Library exhibit demonstrate, the damage that food and drink can do to library books is real but reforming the guilty may be more successful, and less resented, if approached with a touch of humor. But those same issues obviously affect library staff who may be just as accustomed as users to a more casual approach to the consumption of food and drink at work. The imposition of the same, or more stringent, standards on library staff as imposed on users - for after all we must be good role modelscan generate outright hostility to that aspect of the preservation cause that may surface through humor. News Nosey reported, for example, in 1985 on a new series of brown bag lectures to which staff were encouraged to bring their brown bags but without food or drink in them. The continuing cockroach battle at the Ohio State University $\mathrm{Li}$ brary (see box below again)-including the description of the discovery of the largest cockroach species known to man-and other aspects of the battle against food and drink in the library, have been featured there in a humorous context but the dividing lines among the library staff have not been clearly drawn.

But whether in simple jest or in earnest satire the important national library effort to address serious preservation concerns does have its lighter aspects. Just as it has added a new dimension to the serious side of librarianship, so it has added a new dimension to the humorous side. That has been an unanticipated and welcome benefit of this vital work.

\section{Applications invited for C\&RL editor}

Nominations and applications are invited for the position of editor of College \& Research Libraries. The editor is appointed for a three-year term which may be renewed for an additional three years. Applicants must be members of ALA and ACRL. Qualifications include experience in academic libraries, evidence of research and editing activity, and a broad knowledge of the issues confronting academic libraries. A small honorarium for the editor and funding arrangements for editorial assistance are available. Nominations or resumes with names of three references may be sent to: C. Brigid Welch, Chair, College and Research Libraries Search Committee, Central University Library, C-075-R, University of California, San Diego, La Jolla, CA 92093. The deadline for applications is May $1,1989$.

\title{
Library benefit concerts: Blood, sweat, and cash
}

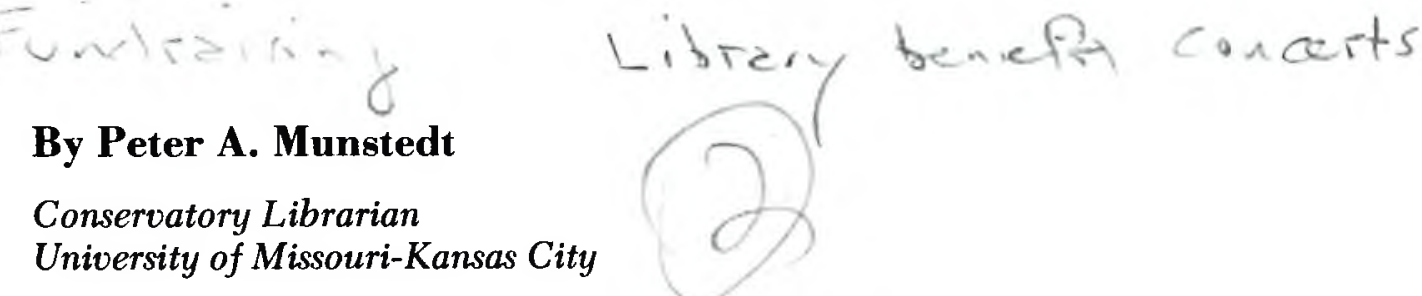

Budget cuts and inadequate funding have increasingly sent academic librarians in search of outside money. Grants are one means of obtaining support, but this funding has become scarce over the years. Finding grants applicable to a library and its particular needs also restricts the possibilities, especially for smaller academic libraries. In these lean financial times for libraries, new and creative approaches are often necessary to supple- ment a budget. As Peter Spyers-Duran points out: "The choice between operative poverty and relative affluence may be determined by the academic library's ability to increase outside support level."1

${ }^{1}$ Peter Spyers-Duran, "Revitalization of Academic Library Programs through Creative FundRaising," in Austerity Management in Academic Libraries, ed. John F. Harvey and Peter Spyers- 
Book auctions, video rentals, walkathons, library-sponsored tours of foreign countries, and sales of library $\mathrm{T}$-shirts are among the innovative ways that libraries have raised money. Unfortunately, some academic librarians lack the time or initiative to consider fundraising events. It is not a subject usually discussed in library school, and one that may seem more applicable to public libraries. But academic librarians should not overlook fundraising and public relations if these efforts will benefit their collections. Fundraising can be an effective means to supplement budgets and promote any library. This money can be spent however needed, unlike grant funding which is often targeted for specific areas such as access or preservation. ${ }^{2}$

Music librarians who serve as liaisons to music departments are fortunate in regard to fundraising since their faculty and students are performing artists. But surprisingly, the link between these performers and fundraising concerts is often overlooked. Convincing the faculty to support such a concert can be a challenge, depending upon the relationship between the library and music department. In addition, the institution's development office must espouse the cause of this event. The amount of time to plan and organize-always longer than anticipated-is also a consideration. Yet in spite of the obstacles, library benefit concerts can be presented with success. The following case study examines a music library benefit concert presented in September 1988 at the University of Missouri-Kansas City.

For approximately three years, the possibility of a benefit concert had been discussed by the Conservatory's Library Committee. This committee, composed of three Conservatory faculty members and the Conservatory librarian, met regularly to discuss library issues. Upon hearing of the library's budgetary problems, the committee pursued the idea of an annual benefit concert, with proceeds going to Conservatory Library acquisitions. The director of libraries, dean of the Conservatory, and the University Development Office approved of this concert, leaving the committee in control of its organization.

Several initial decisions were necessary, not least of which concerned choosing the performers. After considering students and faculty, the idea of

Duran (Metuchen, N.J.: Scarecrow Press, 1984), 82.

${ }^{2}$ There are several books that deal with general principles of fundraising, some of which include musical events. However, these benefit concerts are usually large gala events featuring a Sammy Davis Jr. and $\$ 500$ tickets, events in another stratosphere from most humble libraries. Library literature discusses fundraising techniques, but little about benefit events within academic libraries. Benefit concerts are mentioned in music literature, but these events are usually either million dollar affairs such as Farm Aid or Live Aid, or high school band fundraisers. alumni performers became the most attractive option. The Conservatory Alumni Association welcomed the proposal since this organization had been rather dormant and wished to increase membership activity. There were many local alumni who would enjoy attending this event which could be incorporated within the annual alumni dinner held in September. While the committee was pleased with this response, there was concern about performing standards, as these alumni would be representing the Conservatory. Divisional heads of the Conservatory were contacted by the committee and asked to recommend two or three alumni to perform in this concert. It was hoped to present the finest performers who had remained musically active upon graduation.

The next issue concerned programming the concert. With several diverse performers, a common theme was needed to unite this event. In an effort to reach the community, it was felt that light music would be appropriate. A concert of all popular works, however, would not accurately reflect the Conservatory and its curriculum. Instead, an evening of encore pieces-short, showy works usually played at the end of a recital-would gain community support and properly showcase alumni talents. Performers were asked to choose encore repertoire consisting of pieces that last about five minutes or less. A wide variety of music comprised the program, ranging from Gershwin songs to Chopin waltzes. Performers included two solo pianists, a flutist, a violinist, a soprano, and two dancers. These were local alumni who had generously donated their time. Complimentary tickets and a cassette tape of the concert were all that they received, so this expense was minimal.

During the planning stages, it became evident that an appealing name was needed for the concert. The Conservatory Library Benefit Concert, as it was initially called, lacked the necessary Madison Avenue appeal. Because the concert consisted of encore pieces, and the performers (and several in the audience) were returning students, it was decided to call this an encore concert. To emphasize that it would be held annually, the year was added to the name, so that the initial concert became known as, "Encore '88."

Although the goal was to raise as much money as possible, the realistic objective was to present a successful concert that would be well received and become an annual event. A modest ticket price of $\$ 10$ was charged, and Conservatory students and faculty were granted free admission, so as to encourage a large audience. The two major expenses, a wine and cheese reception and the cost of a staff accompanist, were taken from the concert's proceeds. Although these expenses could have been avoided, they were worthwhile in establishing a quality concert. Most smaller expenses, such as promotional flyers, programs, tickets, and postage, were absorbed by the Conservatory, Library, and Development Office. There was no rental fee 


\section{ACQUISITION PERSPECTIVES}

1. ANY BOOK IN PRINT .

means delivery to your library of all available books from any publisher or distributor in the U.S. or Canada. There is no list of publishers you must check ... WE DELIVER THEM ALL ... including trade, scientific/technical, text, university presses, paperbacks, associations, small presses, Canadian, and software.

Send us your direct orders and experience the "added value" received when using Book House.

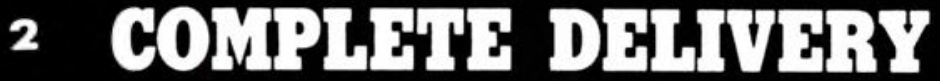

\section{IN THE UNITED STATES} AND CANADA

BOOK HOUSE

AWT BOOR If PRTIT

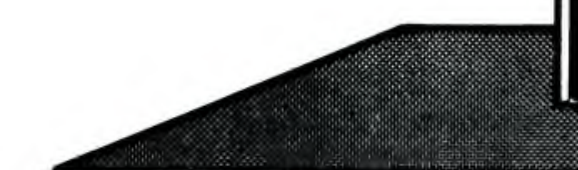

2

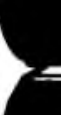

3 OPH ORDAR RAPORTS

4 ECCURATH BOOK DHANAR?

CALL TOLL-FREE TODAY

1-800-248-1146

In Canada \& Michigan

CALL COLLECT (517) 849-2117

OCLC Vendor No. 17397

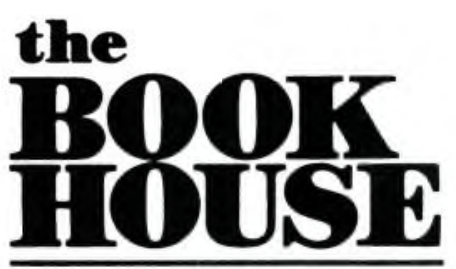

JOBBERS SERVING LIBRARIES WITH ANY BOOK IN PRINT SINCE 1962 208 WEST CHICAGO STREET JONESVILLE, MICHIGAN 49250 
for the Conservatory's recital hall.

Publicity was handled by the Conservatory's publicity department. Promotional flyers, which encouraged donations from those not attending, were mailed to Conservatory alumni and the Friends of the Library. Newspaper announcements along with radio and television appearances by concert performers and the Conservatory librarian not only advertised the concert, but also promoted and publicized the library. Additional exposure was obtained at the concert, where four display cases highlighted the Conservatory Library collections, and handouts about the library were distributed.

"Encore ' 88 " was a great success. An audience of over 200 people attended, and the Library received over $\$ 600$. The program and performers were given rave reviews, and most importantly, enthusiasm was generated for "Encore '89." Word will spread concerning future concerts which should become better attended over the years. The appearance of a "big name" alumnus would also increase ticket sales significantly.

In retrospect, the money raised may not seem to justify the hours of preparation, but there are several benefits other than financial. The Conservatory Library received considerable exposure and publicity which is always welcome, and could pay future dividends. The relationship between the $\mathrm{Li}$ brary, Conservatory, and Development Office was strengthened through this experience. The Conservatory benefited by highlighting impressive alumni who can be the school's best advertising. Alumni were given an opportunity to perform at their alma mater, gain exposure, and convincingly demonstrate the value of their education. A new audience, largely drawn from the community, was introduced to the Conservatory and its many offerings. Only in retrospect was it realized how many people had benefited from this concert.

Plans are being made for "Encore '89." A newlyestablished Encore Concert Committee, consisting of the Conservatory librarian along with represent- atives from the University Development Office, the Conservatory's Publicity and Stage Management Offices, and the Conservatory Alumni Association, will oversee the organization of the next concert with hopes of smoothing out details. A calendar timetable will be created so that each year's committee is certain of all deadlines. The Conservatory's Library Committee will continue to assist in obtaining performers and assembling the program. Only with this university-wide cooperation can these concerts become a reality.

While music librarians should consider establishing such a concert, librarians in other disciplines can also involve their faculty in fundraising events. Departments in any of the performing arts possess obvious possibilities. But what about departments not normally associated with raising money at public events? There could certainly be a poetry reading presented by the English department, an art exhibit given by the art department, or a financial advising workshop sponsored by the business department. Well-known speakers in any subject can generate interest and raise significant funds. Such a speaker could be an alumnus or just a friend of the library and university.

There is no denying that fundraising events take detailed planning, require large amounts of time, and can cause several headaches. But librarians should not underestimate the positive image of libraries in the minds of faculty as well as the general public. During the initial planning of "Encore " 88 ," it was uncertain whether the necessary university-wide support would be received. In disbelief, a music professor stated emphatically that anyone not supporting the library and this concert would surely be opposed to the flag and apple pie. Sympathetic supporters are probably out there, but it is a librarian's responsibility to tap this resource through his or her own initiative. Fundraising through a concert or other event will take considerable effort and creativity, but its many rewards can make it all worthwhile.

\title{
Merchandising library services
}

\author{
By Luella Bosman Teuton \\ Coordinator, Library Services \\ South Florida Community College
}

Returning to the library profession after eight years in the business world has given me a new perspective. Librarians tend to look on our professions as service-oriented only, forgetting that we must also promote and "sell" our product. With funds being cut at many colleges and universities, librari- ans must be constantly demonstrating the value of library facilities and services. In the business world, if the public is not convinced of a product's worth they will not buy it. The end product in library services is not always visible to administrators. The services provided by libraries are often 